\title{
Anti-aging effect and gene expression profiling of dung beetle glycosaminoglycan in aged rats
}

\author{
Mi Young Ahn" ${ }^{*}$, Ban Ji Kim¹, Ha Jeong Kim¹, Jae Sam Hwang ${ }^{1}$, Yi-Sook Jung ${ }^{2}$ and Kun-Koo Park ${ }^{3}$
}

\begin{abstract}
Background: This study aimed to evaluate the anti-aging effect of a newly prepared insect-derived compound, dung beetle glycosaminoglycan (GAG), given intraperitoneally to old SD rats as part of their diet for 1 month. Insect GAG administration was found to be related to a reduction in oxidative damage, hepato-cellular biomarker levels, protein carbonyl content, and malondialdehyde concentration. The anti-aging-related molecular genetic mechanisms of dung beetle GAG are not yet fully elucidated.

Results: Catharsius molossus (a type of dung beetle) GAG (CaG) possessed anti-aging activities; it reduced the serum level of creatinine kinase, had aortic vasorelaxant activities and cardioprotective actions, and maintained a normal glucose level in treated rats. Microarray analysis was performed with a rat $30 \mathrm{~K} \mathrm{cDNA}$ clone set array to identify the gene-expression profiles of 14-month-old SD rats treated with dung beetle glycosaminoglycan $5 \mathrm{mg} / \mathrm{kg}$ (CaG5) over a 1-month period, which was done to investigate its anti-aging effect as compared to that of either Bombus ignitus (a type of bumblebee) queen GAG $5 \mathrm{mg} / \mathrm{kg}$ (IQG5) or chondroitin sulfate $10 \mathrm{mg} / \mathrm{kg}$. CaG5 and IQG5 had marked anti-inflammatory effects, bringing about inhibition of free fatty acid, uric acid, SGPT, IL-1 beta, and CK values. In addition, anticoagulant and antithrombotic effects were seen: the concentration of factor 1 (fibrinogen) was increased in CaG- treated rat plasma. The CaG5-treated rat group, compared to the control, displayed upregulation of 131 genes, including lipocalin 2 (Lbp) and a serine peptidase inhibitor, Kaszal type3 (Spink3), and 64 downregulated genes, including lysyl oxidase (Lox), serine dehydratase (sds), and retinol saturase (Retsat).

Conclusion: Our data suggest that dung beetle glycosaminoglycan may be a helpful treatment for aged rats, which indicates its potential as a therapeutic biomaterial for aging.
\end{abstract}

Keywords: Anti-aging effect, Dung beetle (Catharsius molossus), Queen of B. ignitus, Glycosaminoglycan

\section{Background}

Aging is associated with an increased risk of cardiovascular disease and death [1]. Here, we show that intraperitoneal supplementation with natural insect GAGs exerts cardioprotective effects via vasoconstriction, by reducing the serum level of creatinine kinase in old rats. In fact, although GAGs constitute a minor portion of native tissues, they play a crucial role in various physiological processes [2]. There are many reports that GAGs are

\footnotetext{
* Correspondence: amy@korea.kr

'Department of Agricultural Biology, National Academy of Agricultural Science, Rural Development Administration (RDA), Wanju-Gun 55365, South Korea

Full list of author information is available at the end of the article
}

related to age; they have been implicated in such processes as degeneration of cervical intervertebral discs $[3,4]$, age-related diseases that impair bone healing [5], and prevention of cancer [6]. They have been shown to be associated with age-related changes in matrix components and the onset of diseases of aging, especially cardiovascular pathologies, and are mostly involved in the age-dependence of biological functions and the limitation of longevity [7]. Aging is associated with alterations in the structure of heparin sulfate on the surface of outgrowth endothelial cells. Such changes modulate the migration, homing, and engraftment capacity of these repair cells, thereby contributing to the progression of endothelial dysfunction and age-related vascular pathologies [8]. Edible and medicinal insects have been 
employed, by way of purification, extraction, and identification of potent active constituents, as functional foods or drugs. Extracts of the dung beetle Catharsius molossus, which is found in China, displayed marked fibrinolytic activity and anti-oxidative and anti-hyperglycemic effects on rats fed a high fat diet $[9,10]$. The protein carbonyl content of blood and malondialdehyde concentration of liver tissue treated with dung beetle ethanol or acetone extract over a 1-month period, were significantly decreased compared to the controls [10]. Recently, a Korean dung beetle peptide, LLCIALRKK- $\mathrm{NH}_{2}$, which is a 9-mer peptide derived from Copris tripartitus Coprisin, was found to exert bactericidal activity against E. coli and antimicrobial activity by causing severe DNA damage, which induces apoptosis-like death [11]. An apicultural product, B. ignitus queen (BIQ) alcohol extract has the highest potential efficacy amongst all bumble bee extracts tested for treating inflammation in SD rats, as it significantly reduced paw edema [12]. So, we prepared GAGs derived from the greatest acquirable number of $C$. molossus or B. ignitus queens to test their anti-aging properties. Aging involves a progressive decline in the physiological capacity of an organism, and is manifested by accumulated alterations and destabilization at the whole system level [13]. Aging is also associated with a differential gene expression pattern indicative of a decreased stress response amongst metabolic and biosynthetic genes [14]. In particular, an age- or obesity-related increase in visceral adipose tissue is usually accompanied by low-grade chronic inflammation, which has been postulated as a cause of various metabolic diseases including cancer, cardiovascular diseases, and, most prominently, type two diabetes [15]. These insect GAGs can be used in a fast developing field with the prospect of utilizing tissue engineering and biomaterials as novel therapies [16].

In this study, we report that GAG from dung beetles and BIQ displayed anti-aging properties and, thus, these compounds hold great promises for use as anti-aging agents. Also, we demonstrate the potential value of $C$. molossus dung beetle glycosaminoglycan in lessening the deleterious aspects of aging, as measured both in serum and in the gene expression patterns of 14-month-old SD rats following treatment for 1 month.

\section{Methods}

\section{Materials}

\section{Preparation of insect glycosaminoglycan}

Dried C. molossus was purchased at a local market in China; bumble bee (queen of Bombus ignitus) was reared and freeze-dried, in the Department of Agricultural Biology, National Academy of Agricultural Science, South Korea. Chondroitin sulfate and all reagents were supplied from Sigma Aldrich (St. Louis, Mo., USA).
Each of one-kilogram $(1 \mathrm{~kg})$ dried insect was soaked and extracted three times with ethanol by ultrasonification (Branson, Colorado, MI, USA) for $30 \mathrm{~min}$. The residues separated from the alcohol extracts were defatted twice with 2 volumes of acetone. Approximately $200 \mathrm{~g}$ of dried, defatted and pulverized powder was suspended in $2 \mathrm{~L}$ of $0.05 \mathrm{M}$ sodium carbonate buffer $(\mathrm{pH}$ 9). The suspension was incubated for $48 \mathrm{~h}$ at $60{ }^{\circ} \mathrm{C}$ after adding $28 \mathrm{ml}$ (1.4\%) of Alcalase (Sigma Aldrich, St. Louis, Mo., USA). The digestion mixture was cooled to $4{ }^{\circ} \mathrm{C}$, and trichloroacetic acid was added to a final concentration of $5 \%$. The sample was mixed, allowed to stand for $1 \mathrm{~h}$, and then centrifuged for $30 \mathrm{~min}$ at $8000 \times \mathrm{g}$ (Hanil Science Industrial, Incheon, South Korea). Three volumes of 5\% potassium acetate in ethanol were added to one volume of supernatant. After mixing, the suspension was stored overnight at $4{ }^{\circ} \mathrm{C}$ and then centrifuged. The precipitate amounting to $20 \mathrm{~g}$ was dissolved in $40 \mathrm{ml}$ of $0.2 \mathrm{M} \mathrm{NaCl}$ and centrifuged. Cetylpyridinium chloride (5\%) was added to 0.2 times the volume of the supernatant, and the precipitate was collected by centrifugation. The precipitate was dissolved in $20 \mathrm{ml}$ of $2.5 \mathrm{M} \mathrm{NaCl}$. Five volumes of ethanol were added, and the precipitate was separated by centrifugation. The precipitate was dissolved in water and dialyzed against 100 volumes of water [17], and the dialyzed crude glycosaminoglycan was freeze-dried to obtain about $1.1 \mathrm{~g}$ of $\mathrm{CaG}, 4.89 \mathrm{~g}$ of IQG as a powder. Crude GAG was loaded onto a DEAE Sephadex A-25 gel chromatography column (40 x $1.2 \mathrm{~cm}$ ) equilibrated with $50 \mathrm{mM}$ phosphate buffer (pH 7.4). The fractions were eluted using a linear sodium chloride gradient from 0 to $2.5 \mathrm{M} \mathrm{NaCl}$ in phosphate buffer at a flow rate of $20 \mathrm{ml} / \mathrm{h}$, and the dialyzed glycan was freeze-dried to pure GAG.

\section{Animals}

Sprague Dawley (SD) rats (male), at 8-months of age, were supplied from Samtako Co. Ltd. (Osan, Korea). All procedures were in accordance with the NIH Guidelines for Care and Use of Laboratory Animals. All experiments were approved by the Laboratory Animals' Ethical Committee of the National Academy of Agricultural Science, RDA, South Korea (NAAS1503) and followed national guidelines for the care and use of animals (individual housing). The rats were acclimated for 6 months under normal husbandry conditions $\left(23 \pm 2^{\circ}\right.$ C, $55 \pm 10 \%$ humidity and $12 \mathrm{~h}$ light/dark cycle) and fed a normal diet (D10001, AIN-76A rodent diet, Research Diet Inc., New Brunswick, NJ, USA) and water ad libitum. The 14 month old rats were segregated into 4 treatment groups of 10 rats each and distributed according to similarity in weight $(680.2 \pm 9.20 \mathrm{~g})$. The treatments were given in PBS daily and each administrated intraperitoneally. 
The groups were control, $5 \mathrm{mg} / \mathrm{kg} \mathrm{CaG} \mathrm{(CaG5),} 5 \mathrm{mg} /$ $\mathrm{kg}$ IQG (IQG5), and $10 \mathrm{mg} / \mathrm{kg}$ CS (CS10) (Sigma Aldrich Co., USA), given. Each group was maintained on the normal diet (AIN-76A rodent diet, Research Diet) and sample treatment for 1 month (Scheme 1).

\section{Adipose tissue weights}

Abdominal and epididymidal fat to-body weight ratios were determined. The measurements were after sacrifice at the end of the 1-month treatment period.

\section{Adipocyte density}

The excised organs and adipose tissue were fixed 10\% neutral formalin. After paraffin embedding, they were stained with hematoxylin and eosin, and Toluidine blue O, examined by light microscopy (Leica CTR6000, Hesse, Germany), and photographed. Adipocyte density $\left(\right.$ cells $/ \mathrm{mm}^{2}$ ) was determined in treated and control tissue by toluidine blue $\mathrm{O}$ stain (original magnification, $\mathrm{x} 400$ ).

\section{Blood sampling and blood, plasma, serum assay}

On four groups named CON, CaG5, IQG5, CS10 $(n=10)$, after 1 month of treatment, blood $(\sim 5 \mathrm{ml})$ was collected from the posterior vena cava under light $\mathrm{CO}_{2}$ inhalation and used for serum chemistry measurements. The parameters examined included phospholipid, hyaluronic acid, free fatty acid, albumin, alkaline phosphatase (ALP), glutamic oxaloacetic transaminase (GOT), glutamic pyruvic transaminase (GPT), lactic dehydrogenase (LDH), CK (creatinine phosphokinase), glucose, total cholesterol triglyceride, HDL cholesterol, LDL cholesterol, creatinine, blood urea nitrogen (BUN), total protein, uric acid and creactive protein (CRP). All parameters were evaluated using an autoanalyzer (Hitachi 7060 automatic clinical analyzer, Tokyo).

\section{Blood sampling and plasma assay for anti-coagulant activity detection}

After the 1-month treatments, approximately $4 \mathrm{ml}$ of plasma was collected from the posterior vena cava under light $\mathrm{CO}_{2}$ inhalation and centrifuged. The supernatant was used for clotting time as an anticoagulant activity test: activated partial thromboplastin time (APTT), thrombin time, prothrombin time, and factor 1 (fibrinogen) as a fibrinolytic activity assay using a fore mentioned automatic clinical analyzer according to Green Cross Lab's manual.

\section{Oxidative lipid damage}

To determine the oxidative lipid damage in rat hepatocytes, malondialdehyde (MDA) levels were measured with a lipid peroxidation assay using the color method involving thiobarbituric acid reactive substances (TBARS) at $535 \mathrm{~nm}$ [18].

\section{Oxidative protein damage}

Liver homogenate supernatants and blood, obtained following centrifugation were used for of determination of carbonyl content. Protein oxidative stress was evaluated by measuring protein carbonyl content in the blood. Carbonyl content was determined with an enzymelinked immunoassay according to the manufacturer's protocol for the OxiSelect ${ }^{\text {mix }}$ protein carbonyl ELISA kit (Cell Biolabs, Inc., San Diego, CA, USA). CAT activity (U/mg protein) was measured based on CAT-mediated decomposition of $\mathrm{H}_{2} \mathrm{O}_{2}$ [19].

\section{Liver homogenate preparation for oxidative enzyme detection}

About four groups named CON, CaG5, IQG5, CS10, liver tissues were homogenized on ice in a 10-fold volume lysis buffer PRO-PREP ${ }^{\mathrm{Tx}}$ protein extraction solution (iNtRON, Busan, Korea). The supernatant of the liver homogenate after centrifugation (800 g, $10 \mathrm{~min}$ ) was assayed for catalase, glutathione peroxidase, glutathione s-transferase and superoxide

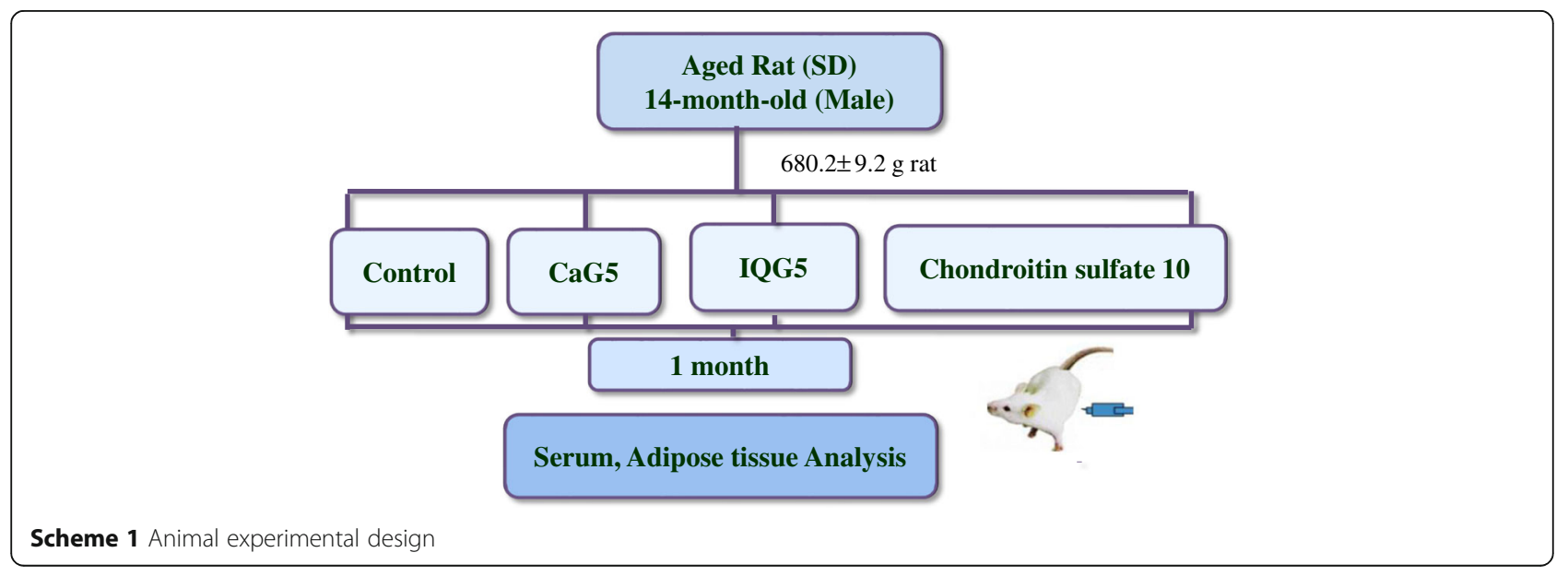


dismutase activity according to assay manual (OxiSelect ${ }^{\mathrm{tm}}$ ELISA kit, Cell BioLabs, InC., San Diego, CA, USA).

\section{Cytokine IL-1 $\beta$, IL- 6 and IL-10 assay}

On four groups named CON, CaG5, IQG5, CS10, the IL$1 \beta$ or $\mathrm{IL}-6$ or $\mathrm{IL}-10$ level in insect GAG-treated rat serum was measured using commercial Elisa kits (Quantikine, R\&D Systems, Inc, Minneapolis, MN, USA) according to the manufacturer's instructions.

\section{RNA preparation and quantitative real-time PCR analysis}

Total RNA was isolated from liver using TRIzol reagent (Invitrogen, Carlsbad, CA, USA), and RNA concentration and purity were measured using a UV/Vis spectrophotometer (Beckman Coulter Co., Miami, FL, USA). Complementary DNA (cDNA) was synthesized from $1 \mathrm{~g}$ of total RNA using the high capacity cDNA Reverse Transcription Kit (Amersham Biosciences Co., Piscataway, NJ, USA). Realtime polymerase chain reaction (PCR) amplification was performed with Power SYBR Green Master Mix using a 7500 Real-Time PCR System (both from Applied Biosystems), according to the manufacturer's instructions. For detection of target gene transcripts, we designed specific forward and reverse oligonucleotide primers using Beacon Designer software (PREMIER Biosoft, Palo Alto, CA, USA). The primer sequences are listed in Scheme 2. Target mRNA levels were normalized using glyceraldehyde 3phosphate dehydrogenase (GAPDH) as an internal control to qualify the relative expression of target mRNA according to the cycling threshold method. All samples were analyzed in triplicate.

Primer sequences for amplification of genes involved in cell repair mechanism and GAPDH internal standard (Scheme 2).

\section{DNA microarray procedure}

After histopathology analysis, microarray hybridization was performed on liver samples [20]. Total RNA was isolated from liver tissue using a Qiagen RNeasy Midi Kit (Qiagen, Valencia, CA, USA). A FairPlay ${ }^{\text {tix }}$ microarray labeling kit (Stratagene, La Jolla, CA, USA) was used according to the manufacturer's instructions. The labeled DNA was loaded onto a microarray chip. A hybridization chamber was assembled with the microarray chip, Rat Genome 2302.0 Array (Affymetrix Inc., Santa Clara, USA), and submerged in a water bath overnight at $60^{\circ} \mathrm{C}$. The microarray chip was washed in wash buffer I, wash buffer II, and then wash buffer III for 5 or $15 \mathrm{~min}$. The slide was dried by centrifuging at $500 \mathrm{~g}$ for $15 \mathrm{~min}$ and scanned with a BMS Array Scanner, applied precision Array WoRx eBiochip Reader (BioRad, Dallas, TX, USA), using the Cy3 and Cy5 channels [21].

\section{Isolated rat heart analysis}

Male Sprague-Dawley rats weighing $350 \pm 50$ g were anesthetized with pentobarbital $(100 \mathrm{mg} / \mathrm{kg})$. The tail vein was injected with heparin $(1000 \mathrm{U} / \mathrm{kg})$, and then the trachea was intubated. While rats were mechanically ventilated with a rodent ventilator (Model 7025; Ugo Basile, Comerio-Varese, Italy), their hearts were perfused in situ with oxygenated modified Krebs-Henseleit bicarbonate buffer by retrograde aortic cannulation. The hearts were then excised and moved to a Langendorff apparatus (Hugo Sachs Electronik, March-Hugstetten, Germany), where they were perfused with oxygenated modified Krebs-Henseleit bicarbonate buffer at a constant perfusion pressure of $75 \mathrm{mmHg}$. A water-filled latex ventricle was introduced through the pulmonary vein and connected to an Isotec pressure transducer (Hugo Sachs Electronik) to measure left ventricular pressure (LVP). The hearts were allowed to equilibrate for $15 \mathrm{~min}$, at which time the left ventricular end-diastolic pressure (EDP) was adjusted to $10 \mathrm{mmHg}$, and this balloon volume was maintained throughout the experiment. Then, baseline contractile function, heart rate, and coronary flow (extracorporeal electromagnetic flow probe; narco Bio-systems, Houston,

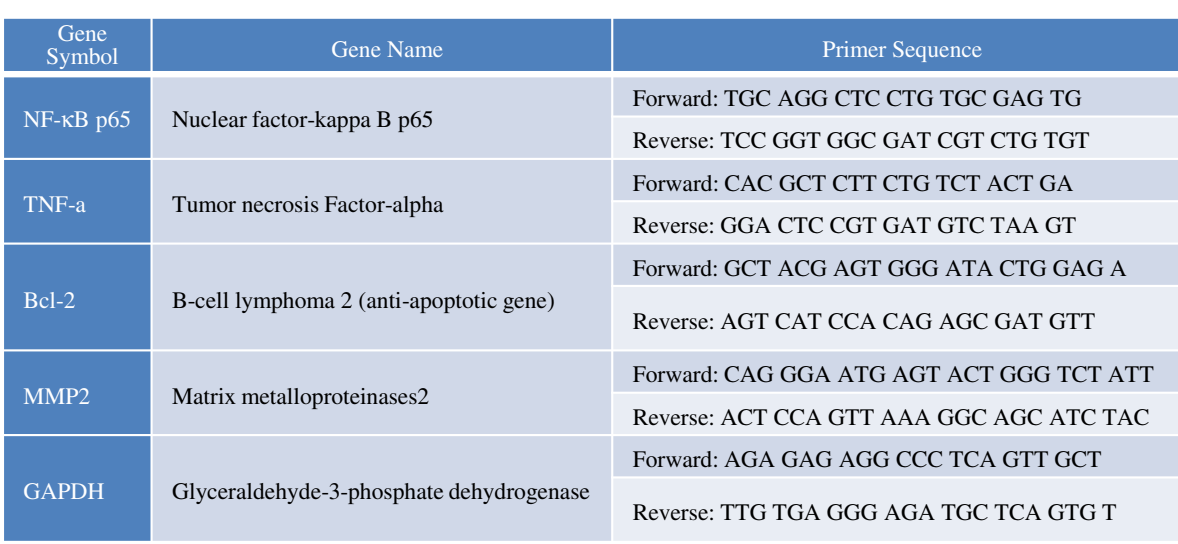

Scheme 2 Primer sequences for amplification of genes involved in cell repair mechanism and GAPDH internal standard 
TX, USA) were measured. Cardiac contractile function was calculated by subtracting LVEDP from LV peak systolic pressure (LVSP), yielding developed pressure (LVDP). After a $1 \mathrm{~h}$ equlibration, aortic rings were treated with vehicle (saline) or CaG $(10 \mu \mathrm{g} / \mathrm{ml}, 100 \mu \mathrm{g} / \mathrm{ml}) 10 \mathrm{~min}$ before contraction was induced by phenylephrine $1 \mu \mathrm{M}$. Then, endothelium-dependent relaxation was induced by acetylcholine $(0.1-100 \mu \mathrm{M})$ [22].

\section{Statistical Analysis}

The means and standard error of all parameters studied were determined for each group using ANOVA test. A Student's $t$-test was carried out to determine significant differences between control and treated groups. A $p$ value $<0.05$ was considered significant.

\section{Results}

\section{Body weight and adipose fat changes}

There were no significant differences in mean body weight between the treatment groups (Fig. 1). During the 1-month administration period, the body weights of the aged male rats were comparable in the control and CaG-, IQG-, and CS-treated groups. The mean weekly body weights are presented in Fig. 2a: CON, $685.16 \pm$ 9.14 g; CaG5, 659.54 \pm 14.21 g; IQG5, $646.50 \pm 11.56$ g, and CS10, $662.93 \pm 7.82 \mathrm{~g}$. The mean quantity of abdominal fat was significantly decreased in the IQG5 and CS10 groups compared to the control: $21.84 \pm 7.46 \mathrm{~g}$ for the control; $20.66 \pm 8.47 \mathrm{~g}$ for CaG5; $16.56 \pm 5.97 \mathrm{~g}$ for IQG5 (IQG5 vs CON, $p<0.05$ ); and $16.93 \pm 5.17 \mathrm{~g}$ for CS10 (CS10 vs CON, $p<0.05$ ) (Fig. 2a). Epididymidal fat was also significantly decreased in the IQG5 and CS10 groups compared to the control: $10.38 \pm 2.58 \mathrm{~g}$ for control; $8.19 \pm 4.00 \mathrm{~g}$ for CaG5; $7.00 \pm 1.35 \mathrm{~g}$ for IQG5

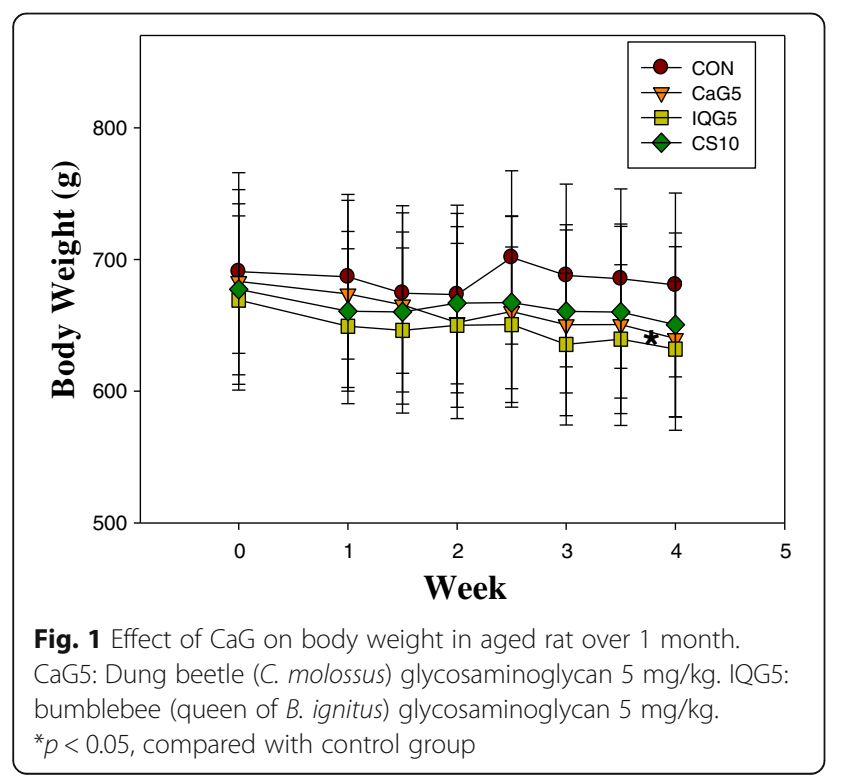

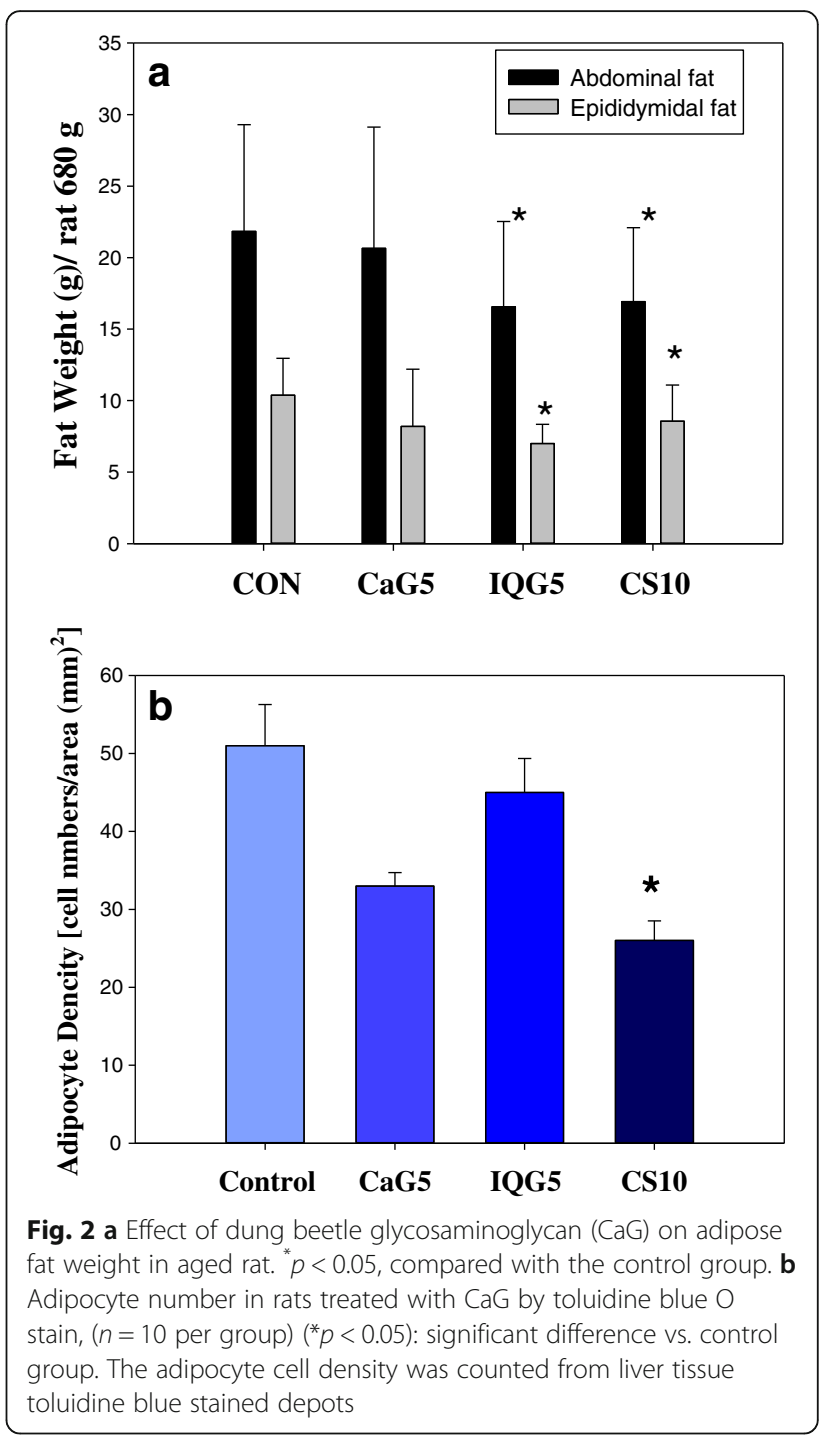

(IQG5 vs CON, $p<0.05$ ); and $8.56 \pm 2.53 \mathrm{~g}$ for CS10 (CS10 vs CON, $p<0.05$ ) (Fig. 2a).

\section{Adipocyte density}

The adipocyte density [number cells/area $\left(\mathrm{mm}^{2}\right)$ ] of rat liver tissues treated with GAG in a HFD, as assessed by toluidine blue $\mathrm{O}$ staining, were reduced by CaG5 (33.00 $\pm 1.73)$, IQG5 (45.00 \pm 4.36$)$, or CS10 (26.00 \pm 2.52$)$ (CS10 vs CON, $p<0.05)$ when compared to the control $(51.00 \pm 5.29)$ (Fig. 2b).

\section{Blood pressure and heart rate changes}

No significant differences in blood pressure (systolic blood pressure or heart rate) were observed between the $5 \mathrm{mg} / \mathrm{kg}$ CaG-, IQG-, or CS-treated groups and the control group (data not shown). 


\section{Hematology and blood chemistry}

Some dose-dependent changes were observed between the treatment and control groups with respect to the hematological parameters examined at the end of the experiment. There was a $27.5 \%$ increase in APTT (sec.) in the CaG5-treated group: CON, $35.68 \pm 5.68$; CaG5, $45.49 \pm 10.91 ;$ IQG5, $29.93 \pm 3.57 ;$ CS10 $36.83 \pm 23.95$ (Fig. 3). Thrombin time (sec.) was as follows: CON, $40.18 \pm 2.04 ; \quad$ CaG5, $42.13 \pm 3.23 ; \quad$ IQG5, $36.15 \pm 6.67$; CS10, $45.02 \pm 21.89$. There was a significant $(62.6 \%)$ increase in Factor I (fibrinogen, $\mathrm{mg} / \mathrm{dL}$ ) in CaG5-treated group: CON, $429.33 \pm 142.22$; CaG5, $698.29 \pm 120.28$ (CaG5 vs CON, $p<0.05$ ); IQG5, 627.14 \pm 160.67 ; CS10, $790.00 \pm 274.22$ (CS10 vs CON, $p<0.05)$. Prothrombin time (sec.) was as follows: CON, $62.86 \pm 47.30$; CaG5, $52.71 \pm 4.96 ;$ IQG5, 52.14 \pm 5.58; CS10, $55.00 \pm 9.92$

\section{Serum biochemistry}

In sera from the IQG- and CS-treated groups (Table 1), phospholipid levels $(\mathrm{mg} / \mathrm{dL})$ were significantly lower than in control sera after 1 month in aged-rats: CON, $271.78 \pm$ 91.74; CaG5, 233.67 \pm 71.0; IQG5, $173.2 \pm 32.02$ (IQG5 vs. CON, $p<0.05$ ); CS10, $259.7 \pm 57.27$ (CS10 vs. CON, $p<$ $0.05)$. Free fatty acid levels $(\mu \mathrm{Eq} / \mathrm{L})$ were decreased: $\mathrm{CON}$, $686.78 \pm$ 104.67; CaG5, $431.33 \pm 66.22$ (CaG5 vs. CON, $p$ $<0.05$ ); IQG5, $405.6 \pm 63.39$ (IQG5 vs. CON, $p<0.05$ ); CS10, $566.9 \pm 115.38$ (CS10 vs. CON, $p<0.05$ ). Also, serum GPT (ALT) levels (IU/L) in the CaG- and IQGtreated groups were significantly lower than those in the control group in aged rats: CON, $76.33 \pm 40.21$; CaG5, $36.78 \pm 8.0 \mathrm{IU} / \mathrm{L} ; \mathrm{IQG} 5,43.22 \pm 13.86$ (IQG5 vs. CON, $p<$ 0.05 ); CS10, $53.44 \pm 11.36$ (CS10 vs. CON, $p<0.05$ ). Furthermore, the mean creatinine phosphokinase (CK U/L) level in the CaG-treated group was lower than that in the

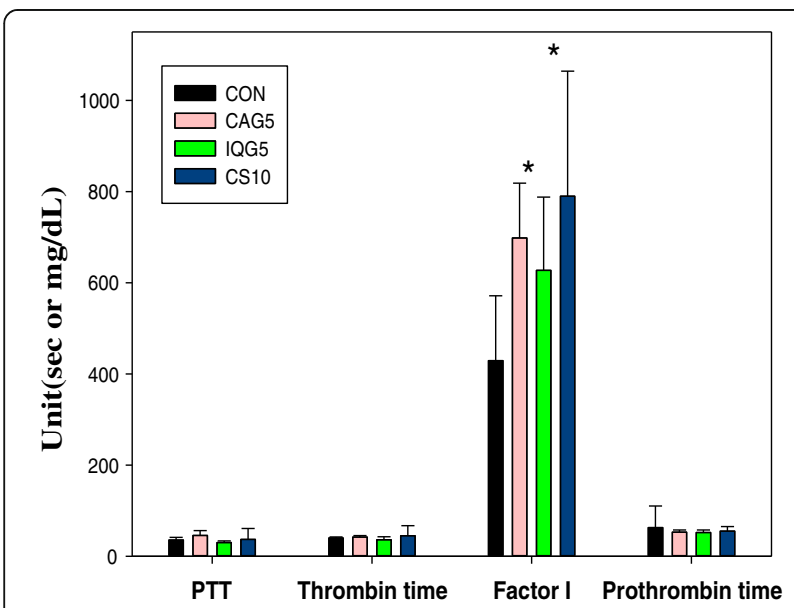

Fig. 3 Anticoagulant activity in plasma level of aged rats treated with $\mathrm{CaG}$ over a month. CON : PBS (as a vehicle) treated with murine normal diet. Each value represents mean \pm S.D. *Statistically significant from the control $(p<0.05)$ control group in aged rats: CON, $125.78 \pm 91.66$; CaG5, $102.89 \pm 65.73$ (CaG5 vs. CON, $p<0.05$ ); IQG5, $91.22 \pm$ 24.74; CS10, $131.2 \pm 62.56$. Mean serum glucose $(\mathrm{mg} / \mathrm{dL})$ was significantly decreased in aged rats (each group $v s$ CON, $p<0.05):$ CON, $435.11 \pm 105.42 ;$ CaG5, $304.0 \pm$ 44.44; IQG5, $275.9 \pm 43.18$; CS10, $317.8 \pm 60.31$.

The mean total cholesterol level $(\mathrm{mg} / \mathrm{dl})$ in the IQGtreated group was lower than in the control group in aged rats, and that difference was also significant: $\mathrm{CON}$, $212.67 \pm 92.82 ;$ CaG5, $181.44 \pm 68.4 ;$ IQG5, $124.1 \pm 23.6$ (IQG5 vs. CON, $p<0.05$ ); CS10, $198.9 \pm 44.43$.

In addition, triglyceride levels $(\mathrm{mg} / \mathrm{dL})$ were as follows: CON, 207.89 \pm 101.95; CaG5, 136.22 \pm 61.6 ; IQG5, 103.3 \pm 35.59 (IQG5 vs. CON, $p<0.05$ ); CS10, $183.4 \pm 104.74$. LDL cholesterol (mg/dL) levels decreased: CON, $74.67 \pm$ 44.91; CaG5, 69.0 \pm 31.3 ; IQG5, 41.44 \pm 10.14 (IQG5 vs. CON, $p<0.05)$; CS10, 65.22 \pm 18.52 . Significant uric acid level $(\mathrm{mg} / \mathrm{dL})$ decreases were seen in all GAG-treated groups as compared with the control (each group vs. CON, $p<0.05)$ : CON, $10.9 \pm 2.26$; CaG5, $8.12 \pm 1.48$; IQG5, $6.49 \pm 0.89$; CS10, $8.14 \pm 2.17$, Table 2 .

\section{Decrease of oxidative damage}

Malondialdehyde (MDA, $\mathrm{nmol} / \mathrm{ml}$ ) was assayed after 1 month of each GAG treatment [CON, 252.9 \pm 13.1 ; CaG5, $175.1 \pm 5.8$ (30.32\% decreases). Each GAG and chondroitin sulfate treatment decreased the lipid peroxidation in hepatocytes (Fig. 4a). The protein carbonyl concentration in blood was decreased at a ratio of 68.52\%, 36.89\% and 53.70\% in GaG5, IQG5 and CS10, respectively (Fig. 4b). But, each GAG had no statistical differences compared with the control in hepatocyte carbonyl content (data not shown).

Oxidative enzyme (catalase, GPx, GST, SOD) quantitation Catalase activity (mg protein/min) in hepatocytes after 1 month of GAG treatment was as follows: CON, $17.72 \pm$ 2.81; CaG5, $19.87 \pm 3.88$; IQG5, $17.22 \pm 4.55$; CS10, $19.23 \pm$ 3.55. Catalase activity in all CaG-treated hepatocyte groups increased. Super oxide dismutase (SOD) is a free radical (super oxide) scavenging enzyme. SOD activity ( $\mathrm{nmol} / \mathrm{min} /$ $\mathrm{ml}$ ) increased in the treatment groups as compared with the control: control, $381.44 \pm 85.32$; CaG5, $400.56 \pm 60.62$; IQG5, 386.72 \pm 69.22; CS10, 513.05 \pm 60.07 . Glutathione peroxidase activity (unit/mg protein) in the CaG-treated hepatocyte group was significantly increased by the treatment (CaG5 vs. CON, $p<0.05$ ), and glutathione stransferase activity $(\mathrm{nmol} / \mathrm{min} / \mathrm{ml})$ in the $\mathrm{CaG}$ group was also significantly increased compared to that in the control group (CaG5 vs. CON, $p<0.05$ ) (Table 2).

\section{Cytokine IL-1 $\beta$ and IL-10 production}

Increases in IL-10 levels were observed in the CaG-treated group. IL-1 $\beta(\mathrm{pg} / \mathrm{ml})$ levels in serum were reduced by 1 
Table 1 Serological findings of aged rats treated with CaG or IQG for 1 month

\begin{tabular}{lllcccc}
\hline Organ function & Parameter & Unit & CON & CaG5 & IQG5 & CS10 \\
\hline Fatty liver & Phospholipid & $\mathrm{mg} / \mathrm{dL}$ & $271.78 \pm 91.74$ & $233.67 \pm 71$ & $173.2 \pm 32.02^{*}$ & $259.7 \pm 57.27^{*}$ \\
& Hyaluronic acid(HA) & $\mathrm{ng} / \mathrm{mL}$ & $36.44 \pm 12.66$ & $30.44 \pm 8.19$ & $35 \pm 2.96$ & $42.89 \pm 22.06$ \\
& Free fatty acid & $\mu \mathrm{Eq} / \mathrm{L}$ & $686.78 \pm 104.67$ & $431.33 \pm 66.22^{*}$ & $405.6 \pm 63.39^{*}$ & $566.9 \pm 115.38^{*}$ \\
Tonic & Albumin(S) & $\mathrm{g} / \mathrm{dL}$ & $4.33 \pm 0.4$ & $3.59 \pm 0.34^{*}$ & $3.52 \pm 0.29^{*}$ & $3.83 \pm 0.36^{*}$ \\
Hepatitis & ALP & $\mathrm{U} / \mathrm{L}$ & $85.44 \pm 27.06$ & $82.89 \pm 19.9$ & $158.9 \pm 39.78$ & $99.89 \pm 22.24$ \\
& AST(SGOT) & $\mathrm{U} / \mathrm{L}$ & $76.67 \pm 34.68$ & $52.22 \pm 10.3$ & $60.89 \pm 5.69$ & $56.33 \pm 12.19$ \\
& ALT(SGPT) & $\mathrm{U} / \mathrm{L}$ & $76.33 \pm 40.21$ & $36.78 \pm 8.0^{*}$ & $43.22 \pm 13.86^{*}$ & $53.44 \pm 11.36^{*}$ \\
& LDH & $\mathrm{U} / \mathrm{L}$ & $500.22 \pm 403.35$ & $247.22 \pm 170$ & $216 \pm 60.61$ & $345.9 \pm 202.14$ \\
Heart Function & CK & $\mathrm{U} / \mathrm{L}$ & $125.78 \pm 91.66$ & $102.89 \pm 65.73^{*}$ & $91.22 \pm 24.74$ & $131.2 \pm 62.56$ \\
Diabetes & Glucose(S) & $\mathrm{mg} / \mathrm{dL}$ & $435.11 \pm 105.42$ & $304 \pm 44.44^{*}$ & $275.9 \pm 43.18^{*}$ & $317.8 \pm 60.31^{*}$ \\
Lipidemia & Cholesterol,total & $\mathrm{mg} / \mathrm{dL}$ & $212.67 \pm 92.82$ & $181.44 \pm 68.4$ & $124.1 \pm 23.6^{*}$ & $198.9 \pm 44.43$ \\
& Triglyceride & $\mathrm{mg} / \mathrm{dL}$ & $207.89 \pm 101.95$ & $136.22 \pm 61.6$ & $103.3 \pm 35.59^{*}$ & $183.4 \pm 104.74$ \\
& LDL Cholesterol & $\mathrm{mg} / \mathrm{dL}$ & $74.67 \pm 44.91$ & $69 \pm 31.3$ & $41.44 \pm 10.14^{*}$ & $65.22 \pm 18.52$ \\
& HDL Cholesterol & $\mathrm{mg} / \mathrm{dL}$ & $110.56 \pm 10.22$ & $92.22 \pm 24.5$ & $78.22 \pm 9.40^{*}$ & $114.2 \pm 7.85$ \\
Rheumatis & Creatinine & $\mathrm{mg} / \mathrm{dL}$ & $0.6 \pm 0.09$ & $0.53 \pm 0.06$ & $0.55 \pm 0.06$ & $0.56 \pm 0.05$ \\
\hline Nepritis & BUN & $\mathrm{mg} / \mathrm{dL}$ & $19.09 \pm 2.45$ & $16.71 \pm 3.07$ & $19.36 \pm 2.91$ & $20.92 \pm 3.27$ \\
& Uric acid & $\mathrm{mg} / \mathrm{dL}$ & $10.9 \pm 2.26$ & $8.12 \pm 1.48^{*}$ & $6.49 \pm 0.89^{*}$ & $8.14 \pm 2.17^{*}$ \\
& Protein,total & $\mathrm{mmol} / \mathrm{L}$ & $7.46 \pm 0.32$ & $6.91 \pm 0.24^{*}$ & $7.23 \pm 0.25$ & $7.23 \pm 0.35$ \\
& CRP(HS) & $\mathrm{mg} / \mathrm{L}$ & $0.51 \pm 0.48$ & $0.32 \pm 0.13$ & $0.42 \pm 0.24$ & $0.31 \pm 0.19$ \\
\hline
\end{tabular}

Each value represents mean \pm S.D. Asterisk marks $\left({ }^{*}\right)$ mean significant differences compared with the control (PBS) group $(p<0.05)$

month of CaG or IQG treatment, demonstrating the compounds' anti-inflammatory actions: control, $251.3 \pm 70.7$; CaG5, $102.9 \pm 9.5 ;$ IQG5, 110.4 $\pm 5.2 ;$ CS10, $110.4 \pm 10.1$ (each group vs. CON, $p<0.05)$. IL-10 activity $(\rho g / \mathrm{ml})$ after 1 month of $\mathrm{CaG}$ treatment in rats was increased: $\mathrm{CON}$, $34.9 \pm 11.5$; CaG5, $67.4 \pm 13.3$ (CaG5 vs. CON, $p<0.05$ ); IQG5, $55.5 \pm 24.7 ;$ CS10, $28.0 \pm 3.8$ (Fig. 5). The IL-10 levels in the CS10 group, was statistically different from that in the CON group (CS10 vs. CON, $p<0.05)$.

\section{Gene expression by quantitative real-time PCR analysis} The data represented that PCR cycle required number (Ct value) when concentration of PCR amplicon are equilibrated by sample amplicon. Median CT values of 5 sample's represented, but there was no different from control group ( $\mathrm{Ct}$ vale $>2.0$ ) on used primer sequence (data not shown).

\section{DNA microarray}

Microarray analysis using a Mouse $28 \mathrm{~K}$ cDNA clone array was performed in order to identify the geneexpression profiles in CaG, IQG, and CS-treated 15month-old SD rat livers, and to provide information on potential anti-aging markers.

Compared to the control group, the CaG5 group exhibited a 2- to 4-fold increase in 118 genes, a 4- 8-fold increase in 11 genes, and a greater than 8 -fold increase in 2 genes. The expression levels of the remaining $\sim 30,000$ genes remained the same. Sixty genes were downregulated from 2- to 4-fold, and 4 showed a 4- to 8 -fold decrease.

In the IQG5 group as compared to the control group, 162 genes increased by 2- to 4-fold, 10 genes increased by 4 - to 8 -fold, and 3 genes increased by more than 8 fold. On the other hand, 66 were downregulated by 2- to 4 -fold and 7 were reduced by 4 - to 8 -fold.

Table 2 Antioxidant enzyme activities of dung beetle glycosaminoglycan in aged rat liver

\begin{tabular}{llcccc}
\hline Oxydative enzyme & Unit & CON & CaG5 & IQG5 & CS10 \\
\hline Catalase & mg protein/min & $14.77 \pm 2.81$ & $21.18 \pm 3.88$ & $15.8 \pm 4.55$ & $16.73 \pm 3.55$ \\
Glutathione peroxidase & Unit/mg protein & $2.46 \pm 0.15$ & $2.59 \pm 0.14^{*}$ & $2.48 \pm 0.21$ & $2.59 \pm 0.1$ \\
Glutathione-s-transeferase & $\mathrm{nmol} / \mathrm{min} / \mathrm{ml}$ & $3.07 \pm 0.09$ & $3.52 \pm 0.24^{*}$ & $3.04 \pm 0.10$ & $3.37 \pm 0.07$ \\
Superoxide dismutase & $\mathrm{nmol} / \mathrm{min} / \mathrm{ml}$ & $381.44 \pm 85.32$ & $400.56 \pm 60.62$ & $386.72 \pm 69.22$ & $513.23 \pm 60.07$
\end{tabular}

Each value represents mean \pm S.E. Asterisk marks $\left(^{*}\right)$ mean significant differences compared with the control (PBS) group $(p<0.05)$ 


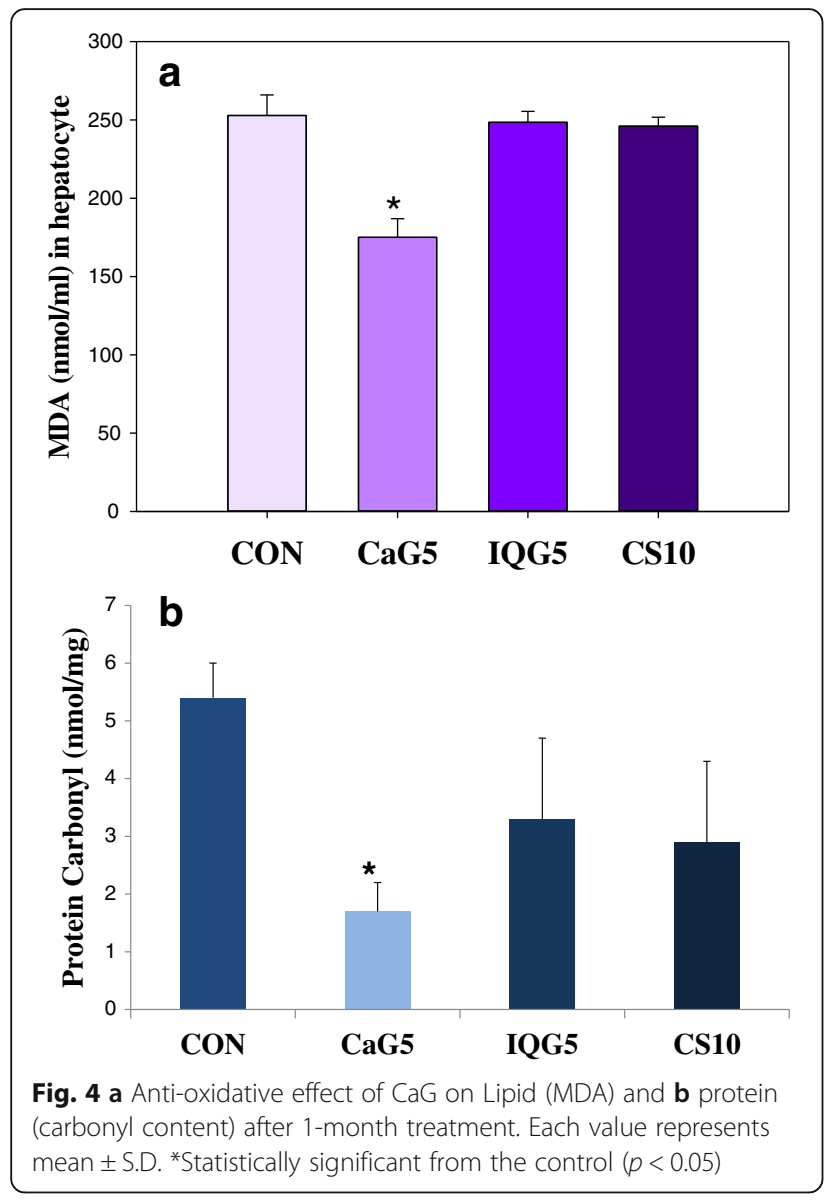

In the CS10 group as compared to the control group 63 genes were upregulated by 2 - to 4 -fold, 2 genes increased by 4- to 8-fold, and 2 genes were upregulated by more than 8 fold. Thirty-eight genes were downregulated by 2- to 4-fold, 4 were downregulated by 4 - to 8 -fold, and 4 decreased by more than 8-fold.

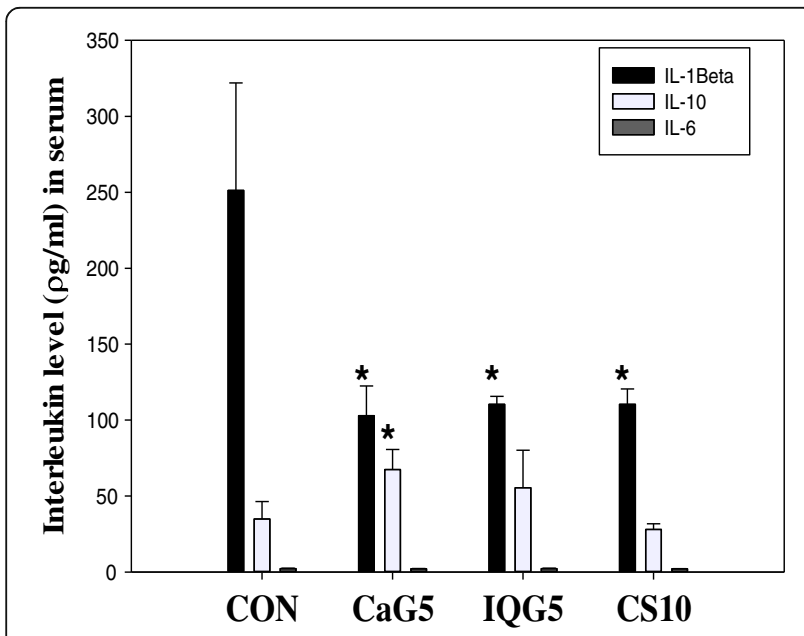

Fig. 5 Interleukin level (IL-1beta, IL-6 or IL-10) of aged rats treated with CaG
When compared to the control group, the lipocalin2 (Lcn2) gene was increased by about 10-fold in CaG5treated liver tissue, 46-fold in the IQ5 group, and 23-fold in the CS10 group. In liver tissues of CaG5-treated mice, lysil oxidase (Lox) was downregulated at a 0.13 ratio, that is, gene expression was decreased. CaG5 treated rat group, compared to control, showed that 131 genes including lipocalin 2, liposaccharide binding protein (Lbp), and serine peptidase inhibitor, Kaszal type3 (Spink3) were upregulated (Table 3) and 64 genes including lysyl oxidase (Lox), serine dehydratase (sds) and retinol saturase (Retsat) were down-regulated (Table 4). The CaG5-treated group, compared to the control group, exhibited an upregulation of 131 genes, including lipocalin 2, liposaccharide binding protein (Lbp), and the serine peptidase inhibitor Kaszal type 3 (Spink3) (Table 3) and a downregulation of 64 genes, including lysyl oxidase (Lox), serine dehydratase (sds), and retinol saturase (Retsat) (Table 4). These data point to lipocalin 2 and adipokines, as upregulated genes, and lysyl oxidase (related to heparanase), as a downregulated gene, as potential therapeutic markers that work against aging and obesity

\section{Characterization of $\mathrm{CaG}$}

The compositions of the amino, acidic, and neutral monosaccharides of $\mathrm{GaG}$ were determined by GC-MS (Table 5). The primary amino monosaccharides of $\mathrm{CaG}$ are in the following order: D-glucosaminic acid $>\mathrm{N}$-acetyl-galactosamine $>\mathrm{N}$-acetyl-D-gactosaminitol $>$ galactosamine $\mathrm{HCl}>$ galactosaminic acid $>$ galactosamine $>$ glucuronic acid. Also, the neutral monosaccharides found in $\mathrm{CaG}$ are mainly $\alpha$ glucose and mannitol, whereas the minor ones include arabinose and rhamnose.

\section{Indicators of cardioprotection}

In this experiment, we characterized the direct effect of $\mathrm{CaG}$ on resistance arteries using vessels incubated in vitro with phenylephrine-induced contraction and acetylcholineinduced relaxation. $\mathrm{CaG}$ was evaluated as a cardioprotective agent. The concentration-response curve to $\mathrm{CaG}$ was shifted downwards compared that seen after control (PBS only) treatment, showing that heart stimulation occurred in a concentration-dependent manner (Fig. 6).

\section{Discussion}

Aging is a process of progressive decline in the physiological capacity of an organism, manifested by accumulated alterations and destabilization at the whole system level [13]. Glycosaminoglycan is thought to diminish the deleterious effects of aging by preventing the destruction of cartilage, bone, discs, skin [23], the vascular system [8], etc. Recently, A type of GAG as a multifunctional materials, heparin base polyurethane or are considered currently as one of the established biocompatible and blood compatible 
Table 3 Upregulated genes differentially expressed in the liver tissue of aged rats

\begin{tabular}{|c|c|c|c|c|c|}
\hline & CaG5 & IQG5 & CS10 & Description & Gene Symbol \\
\hline 1 & $10.69^{*}$ & 45.83 & 23.12 & lipocalin 2 & Len2 \\
\hline 2 & 8.15 & 3.42 & 1.74 & chemokine (C-X-C motif) ligand 1 (melanoma growth stimulating activity, alpha) & Cxcl1 \\
\hline 3 & 6.76 & 12.07 & 3.15 & S100 calcium binding protein A8 & S100a8 \\
\hline 4 & 6.16 & 3.62 & 3.61 & abhydrolase domain containing 3 & Abhd3 \\
\hline 5 & 5.21 & 3.56 & 5.38 & alpha-2-macroglobulin & $\mathrm{A} 2 \mathrm{~m}$ \\
\hline 6 & 4.81 & 3.17 & 5.65 & myxovirus (influenza virus) resistance 2 & $M \times 2$ \\
\hline 7 & 4.75 & 7.36 & 9.85 & WDNM1 homolog & LOC360228 \\
\hline 8 & 4.45 & 1.79 & 1.22 & solute carrier family 13 (sodium-dependent citrate transporter), member 5 & Slc13a5 \\
\hline 9 & 4.39 & 6.16 & 1.85 & S100 calcium binding protein A9 & S100a9 \\
\hline 10 & 4.36 & 1.71 & 1.64 & metallothionein $2 \mathrm{~A}$ & $\mathrm{Mt} 2 \mathrm{~A}$ \\
\hline 11 & 4.06 & 2.23 & 1.37 & kininogen 1-like 1 & Kng111 \\
\hline 12 & 3.95 & 2.26 & 2.35 & ATP-binding cassette, sub-family G (WHITE), member 2 & Abcg2 \\
\hline 13 & 3.62 & 1.95 & 1.85 & protocadherin 18 & Pcdh18 \\
\hline 14 & 3.52 & 2.08 & 1.51 & signal-regulatory protein alpha & Sirpa \\
\hline 15 & 3.50 & 2.84 & 2.64 & lipopolysaccharide binding protein & Lbp \\
\hline 16 & 3.46 & 3.94 & 3.51 & serine peptidase inhibitor, Kazal type 3 & Spink3 \\
\hline 17 & 3.36 & 4.48 & 2.76 & CD36 molecule (thrombospondin receptor) & $\mathrm{Cd} 36$ \\
\hline 18 & 3.15 & 2.92 & 2.57 & serine (or cysteine) peptidase inhibitor, clade A (alpha-1 antiproteinase, antitrypsin), member 7 & Serpina7 \\
\hline 19 & 3.11 & 1.34 & 2.03 & endothelial cell-specific molecule 1 & Esm1 \\
\hline 20 & 3.03 & 2.09 & 1.03 & transglutaminase 1 , $\mathrm{K}$ polypeptide & Tgm1 \\
\hline 21 & 2.97 & 1.67 & 0.84 & basic helix-loop-helix family, member a15 & Bhlha15 \\
\hline 22 & 2.97 & 1.70 & 1.26 & growth arrest and DNA-damage-inducible, beta & Gadd45b \\
\hline 23 & 2.87 & 2.53 & 2.44 & flavin containing monooxygenase 5 & Fmo5 \\
\hline 24 & 2.86 & 3.52 & 3.16 & serine peptidase inhibitor, Kazal type 3 & Spink3 \\
\hline 25 & 2.86 & 4.39 & 2.74 & cytochrome P450, family 7, subfamily a, polypeptide 1 & Cyp7a1 \\
\hline 26 & 2.85 & 1.75 & 1.47 & phosphoinositide-3-kinase, class 3 & Pik3c3 \\
\hline 27 & 2.83 & 1.57 & 1.84 & solute carrier family 10 (sodium/bile acid cotransporter family), member 2 & Slc10a2 \\
\hline 28 & 2.80 & 1.45 & 1.62 & neuron navigator 2 & Nav2 \\
\hline 29 & 2.78 & 2.68 & 1.61 & stefin A2-like 3 & Stfa2l3 \\
\hline 30 & 2.76 & 1.60 & 1.01 & STEAP family member 4 & Steap4 \\
\hline 31 & 2.72 & 1.90 & 1.40 & desmocollin 2 & Dsc2 \\
\hline 32 & 2.71 & 1.68 & 1.63 & lin-7 homolog a (C. elegans) & Lin7a \\
\hline 33 & 2.71 & 2.21 & 2.01 & tumor necrosis factor receptor superfamily, member 21 & Tnfrsf21 \\
\hline 34 & 2.71 & 1.65 & 1.78 & metallothionein 1a & Mt1a \\
\hline 35 & 2.68 & 1.32 & 1.02 & interleukin 34 & 1134 \\
\hline 36 & 2.66 & 1.91 & 1.82 & Lanosterol synthase (2,3-oxidosqualene-lanosterol cyclase) & LSS \\
\hline 37 & 2.66 & 1.60 & 1.24 & interleukin 1 receptor, type $\|$ & $\| 1 \mathrm{r} 2$ \\
\hline 38 & 2.65 & 1.87 & 1.61 & growth arrest specific 6 & Gas6 \\
\hline 39 & 2.64 & 4.31 & 1.99 & interleukin 1 beta & $\| 1 \mathrm{~b}$ \\
\hline 40 & 2.63 & 2.04 & 1.75 & sema domain, immunoglobulin domain (lg), short basic domain, secreted, (semaphorin) 3C & Sema3c \\
\hline
\end{tabular}

*Corrected for background intensity using local background correction

biomaterials offering tremendous structure-property relationship such as a heparin immobilization on chitosan modified polyurethane grafts with anti-adhesive and antimicrobial properties [24]. Nowadays, the advent of temperature control has made possible the design of largescale insect rearing systems. Therefore, glycosaminoglycan 
Table 4 Downregulated genes differentially expressed in the liver tissue of aged rats

\begin{tabular}{|c|c|c|c|c|c|}
\hline & CaG5 & IQG5 & CS10 & Description & Gene Symbol \\
\hline 1 & 0.13 & 0.35 & 0.20 & lysyl oxidase & Lox \\
\hline 2 & 0.19 & 0.53 & 0.75 & similar to Spindlin-like protein 2 (SPIN-2) & LOC367746 \\
\hline 3 & 0.24 & 0.42 & 0.90 & serine dehydratase & Sds \\
\hline 4 & 0.28 & 0.24 & 0.63 & cytokine inducible $\mathrm{SH} 2$-containing protein & Cish \\
\hline 5 & 0.29 & 0.64 & 0.65 & retinol saturase (all trans retinol 13,14 reductase) & Retsat \\
\hline 6 & 0.35 & 0.45 & 0.62 & similar to hypothetical protein MGC42105 & RGD1308116 \\
\hline 7 & 0.36 & 0.28 & 0.39 & solute carrier family 25 , member 30 & Slc25a30 \\
\hline 8 & 0.36 & 1.01 & 0.39 & aldo-keto reductase family 1 , member $\mathrm{B} 7$ & Akr1b7 \\
\hline 9 & 0.37 & 0.19 & 0.26 & one cut homeobox 1 & Onecut1 \\
\hline 10 & 0.38 & 0.66 & 0.68 & CCR4 carbon catabolite repression 4-like (S. cerevisiae) & Ccrn4l \\
\hline 11 & 0.38 & 0.62 & 1.58 & patatin-like phospholipase domain containing 3 & Pnpla3 \\
\hline 12 & 0.38 & 0.49 & 0.95 & myotubularin related protein 7 & Mtmr7 \\
\hline 13 & 0.39 & 0.18 & 0.26 & one cut homeobox 1 & Onecut1 \\
\hline 14 & 0.40 & 0.85 & 1.11 & keratin 10 & Krt10 \\
\hline 15 & 0.40 & 0.99 & 0.85 & cytochrome P450, family 17 , subfamily a, polypeptide 1 & Cyp17a1 \\
\hline 16 & 0.41 & 0.88 & 1.07 & glutamate receptor, ionotrophic, AMPA 3 & Gria3 \\
\hline 17 & 0.41 & 0.70 & 0.65 & CAMP responsive element modulator & Crem \\
\hline 18 & 0.41 & 0.96 & 1.46 & glycerol-3-phosphate acyltransferase, mitochondrial & Gpam \\
\hline 19 & 0.42 & 1.00 & 1.49 & sulfotransferase family, cytosolic, 1C, member 2 & Sult1c2 \\
\hline 20 & 0.42 & 0.30 & 0.44 & family with sequence similarity 89 , member $A$ & Fam89a \\
\hline 21 & 0.42 & 0.32 & 0.34 & solute carrier family 25 , member 30 & Slc25a30 \\
\hline 22 & 0.42 & 1.20 & 0.98 & integrin, alpha 1 & |tga1 \\
\hline 23 & 0.45 & 0.73 & 0.80 & glutamic-oxaloacetic transaminase 1, soluble (aspartate aminotransferase 1) & Got1 \\
\hline 24 & 0.45 & 1.29 & 1.05 & guanine nucleotide binding protein, alpha 14 & Gna14 \\
\hline 25 & 0.45 & 0.37 & 0.76 & similar to Urinary protein 3 precursor (RUP-3)///similar to Urinary protein 2 precursor (RUP-2) & LOC68 0367///LO \\
\hline 26 & 0.46 & 0.81 & 0.74 & similar to Maltase-glucoamylase, intestinal & LOC679818 \\
\hline 27 & 0.46 & 0.63 & 0.69 & ADAM metallopeptidase domain 8 & Adam8 \\
\hline 28 & 0.46 & 0.63 & 0.74 & G0/G1switch 2 & G0s2 \\
\hline 29 & 0.46 & 0.65 & 0.70 & somatostatin receptor 3 & Sstr3 \\
\hline 30 & 0.46 & 0.58 & 0.69 & CAMP responsive element modulator & Crem \\
\hline 31 & 0.47 & 0.57 & 0.56 & RRS1 ribosome biogenesis regulator homolog (S. cerevisiae) & Rrs1 \\
\hline 32 & 0.47 & 0.49 & 0.50 & choline kinase alpha & Chka \\
\hline 33 & 0.47 & 0.70 & 0.86 & early growth response 1 & Egr1 \\
\hline 34 & 0.48 & 0.45 & 0.37 & G patch domain containing 4 & Gpatch4 \\
\hline 35 & 0.48 & 1.15 & 1.11 & similar to ovostatin-2 & RGD1565709 \\
\hline 36 & 0.48 & 0.42 & 0.66 & regulator of G-protein signaling 3 & Rgs3 \\
\hline 37 & 0.49 & 0.65 & 0.51 & tsukushin & Tsku \\
\hline 38 & 0.49 & 0.75 & 1.58 & mesenchyme homeobox 2 & Meox2 \\
\hline 39 & 0.49 & 0.87 & 0.71 & cyclin D1 & Cond 1 \\
\hline 40 & 0.49 & 0.39 & 1.45 & phosphoglycerate dehydrogenase & Phgdh \\
\hline
\end{tabular}

PairMean ratio* means pair Mean ratio (test/control)

can be acquired from the insect cortex as an alcohol extract residues. Such crude drugs from dung beetles and B. ignitus queens have been studied in an effort to identify their active components or to make the extracts safer for human use. The dung beetle $C$. molossus was purified to yield $\mathrm{N}$-acetyldopamine dimers, molossusamide A-C (1-3), showing 
Table 5 Monosaccharide composition of used $\mathrm{CaG}$

\begin{tabular}{lrlr}
\hline Acidic and amino sugar & \multicolumn{1}{c}{$\begin{array}{l}\mathrm{CaG} \\
(\mu \mathrm{g} / \mathrm{mg})\end{array}$} & $\begin{array}{l}\text { Monosugar } \\
(\mathrm{ng} / \mathrm{mg})\end{array}$ & $\mathrm{CaG}$ \\
\hline D-Glucuronic Acid & 8.02 & Arabinose & 8.79 \\
Glucosamine HCl & 10.21 & Rhamnose & 7.04 \\
Galactosamine HCl & 52.17 & Ribose & 4.72 \\
N-Acetyl-Glucosamine & 184.38 & Mannose & 1.26 \\
D-Glucosaminic Acid & 187.96 & Galactose & 0.92 \\
D- Galactosamic Acid & 59.95 & a-glucose & 13.89 \\
N-Acetyl-DGalactosaminitol & 55.50 & Mannitol & 84.16 \\
Total Sum & 558.20 & B-glucose & 4.12 \\
\hline
\end{tabular}

COX-1 and COX-2 inhibitory activity [25]; chitosan [26]; melanin [27]; and serine proteases [9, 28]. A bumblebee (Bombus ignitus) extract was shown to contain bee venom serine protease [29], peroxiredoxins [30], and peptidoglycan recognition protein (PGRP-S) [31].

Strategies to prevent or delay aging have included ingestion of antioxidants for repairing oxidative cellular damage to DNA, proteins, and lipids, as well as stem cell-mediated tissue regeneration and gene therapy [32]. As a lipid oxidative damage marker in hepatocyte lipid oxidative stress states, malondialdehyde was decreased by $\mathrm{CaG}$ treatment. Also, carbonyl content in blood, especially neutrophil, was decreased by CAG treatment and showed repairing cellular oxidative protein damage.

Glycosaminoglycans from C. molossus and B. ignitus queens consist mainly of D-glucosaminic acid as an acidic monosaccharide and $\mathrm{N}$-acetyl-galactosaminitol as an amino

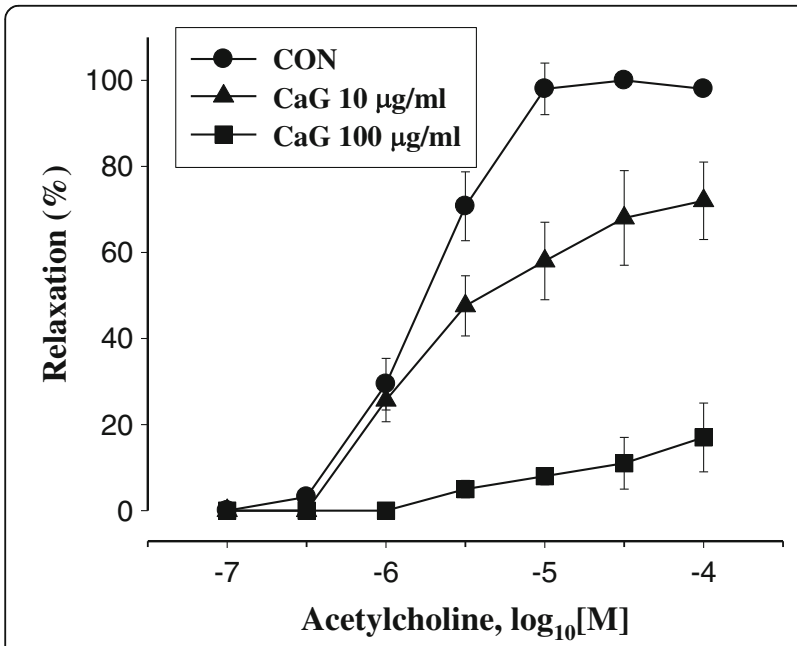

Fig. 6 Effect of $\mathrm{CaG}$ on endothelium-dependent relaxation in isolated aortic rings from normal rat $(N=6)$. After 1 h-equlibration, aortic rings were treated with vehicle (saline) or Catharsius GAG $(10 \mu \mathrm{g} / \mathrm{ml}, 100 \mu \mathrm{g} / \mathrm{ml}) 10 \mathrm{~min}$ before contraction was induced by phenyleprine $1 \mu \mathrm{M}$. Then, endothelium-dependent relaxation was induced by acethylcholine $(0.1 \sim 100 \mu \mathrm{M})$ monosaccharide, along with $\alpha$-glucose and D-mannitol as neutral monosaccharides. Thus, the compound can access cell membrane receptors and can prevent the causes of agerelated diseases by altering energy metabolism. Glycosaminoglycans could repair connective tissues [23], eroded cartilage, discs, bone, and glycoproteins at the molecular level, with GAG forming a bond between proteins [9]. In this experiment, the rats used were old and weighed about $680 \mathrm{~g}$, so, it would not have been easy to bring about a reduction in body weight, but we did observe diminished adipose fat weight and adipocyte numbers. As with most glycosaminoglycans, CaG and IQG brought about a reduction in serum levels of inflammation-related parameters: free fatty acid, AST (SGPT), creatinine kinase (related heart function), glucose, uric acid, and hyperglycemia related levels: cholesterol, total, triglyceride, LDL cholesterol, etc. The free fatty acid levels (related fatty liver) of the treated groups were statistically significantly decreased, $36.7 \%$ in the $\mathrm{CaG}$ group and $40.94 \%$ in the IQG group. Also, the sGPT level (related liver function) was significantly reduced, $51.58 \%$ in the $\mathrm{CaG}$ group and $43.38 \%$ in the IQG group.

Data generated from the DNA microarray analysis supported the anti-aging effect of IQG, with meaningful changes in gene expression profiles in 14-month-old SD rats observed after a 1-month treatment period. The CaG5-treated rats, compared to the control group, had increases in 131 genes, including lipocalin 2 [33], liposaccharide binding protein (Lbp) [34], and a serine peptidase inhibitor, Kazal type3 (Spink3) [35] and decreases in 64 genes, including lysyl oxidase (Lox) [36], serine dehydratase (sds) [37], and retinol saturase (Retsat) [38]. The data point to lipocalin 2 and adipokines, which were up-regulated, and lysyl oxidase (related to heparanase), which was down-regulated, as potential therapeutic markers for anti-aging effects in obese animals.

The present study observed meaningful changes in gene expression profiles in aged rats after treatment with $\mathrm{CaG}$ or IQG for 1 month. The gene expression of lipocalin-2, which is an adipokine implicated in insulin resistance [39] and a secretory protein with lipid-binding prosperities, was increased by about 10 times. This is in agreement with a microarray study that reported that ingestion of soybeans causes an increase of an endogenous amyloid- $\beta$ chaperone, lipocalin-type prostaglandin D2 synthase (Ptgds), leading to suppression of amyloid- $\beta$ and preventing cognitive dysfunction [40]. Lipopolysaccharide (LPS) binding protein (LBP), a surrogate marker of microbial translocation, is associated with reduced physical function and increased inflammation [41]. The normal aging process alters blood coagulation system in humans; Natural anticoagulants, including antithrombin III, heparin cofactor II, protein C, protein S, and tissue factor pathway inhibitor, can modulate the reactions of blood coagulation system [42]. In this study, there were significant increases in factor I (fibrinogen) in CaG (162.6\%), 
IQG (146.0\%), and CS10 (184.0\%)-treated groups when compared to the control, PBS-treated group. Also, the level of LBP (LPS binding protein) was upregulated in our DNA microarray data, suggesting that heparin (GAG) binds to LBP, facilitates the transfer of LPS to CD14, and enhances LPS-mediated activation of peripheral blood monocytes, resulting in anticoagulant activity [43]. A trypsin inhibitor, serine protease inhibitor Kazal-type 3 (Spink3), was upregulated in this experiment, indicating a role for paracrine modulation; it is also involved in embryo implantation [44]. As Spink3 is an important serine protease inhibitor, its upregulation may reflect an important endogenous cytoprotective mechanism that would prevent further injury [45]. The downregulation of lysyl oxidase may indicate that heparin (GAG) inhibiting the tight binding of lysyl oxidase to preformed fibrils was hardly affected [46]. The downregulation of retinol saturase seen in this experiment is notable, as retinol saturase promotes adipogenesis and is downregulated in obesity [47]. According to a hypothesis, adipose tissue density, a novel biomarker predicting mortality risk in older adult's that does not appear to be inflammation related [48], furthermore, $\mathrm{CaG}$ reduced significantly adipose density promising potent anti-aging agent.

\section{Conclusions}

Dung beetle glycosaminoglycan decreased cholesterol and triglyceride levels in serum, caused a decrease in the weight of adipose tissue and a normalization of serum levels of free fatty acid, GPT, glucose, and uric acid, and a prolongation of coagulation time that would prevent blood aggregation and lipid accumulation in vascular endothelial barriers that contribute to homeostasis in the circulatory system. IL- $1 \beta(\mathrm{pg} / \mathrm{ml})$ in serum was reduced by 1 month of CaG or IQG treatment, demonstrating anti-inflammatory action. In addition, the liver protective gene lipocalin was highly (10-fold) upregulated and lysyl oxidase was downregulated (0.1-fold) in $\mathrm{CaG}$-treated rats. $\mathrm{CaG}$ derived from insects could be a safer replacement for heparin and other GAGs from mammalian sources, as insect sources reduce the possibility of transmission of infectious viruses from animals such as pigs. These results suggest that $\mathrm{CaG}$ and $\mathrm{BIQ}$ could not only be natural anti-aging agents but also be functional foods, similar to chitosan and future biomaterials playing vital role our to-day to day life.

\footnotetext{
Abbreviations

ALP: Alkaline phosphatase; ALT(GPT): Glutamate pyruvate transaminase; aPTT: Activated partial thromboplastin time; AST(GOT): Glutamate oxaloacetate transaminase; BUN: Blood urea nitrogen; CaG 5: Dung beetle (Catharsius molossus) glycosaminoglycan 5 mg/kg; CK: Creatinine phosphokinase; CON: Control group; CRP: C-reactive protein; CS10: Chondroitin sulfate (10 mg/kg); GAG: Glycosaminoglycan; GGT: Yglutamyl transferase; H. Chol: High cholesterol; IQG5: Queen of Bombus ignitus (a type of bumblebee) glycosaminoglycan $5 \mathrm{mg} / \mathrm{kg}$; I.Chol: Low cholesterol; LDH: Lactate dehydrogenase; PT: Prothrombin time; T. Chol: Total cholesterol; TG: Triglyceride
}

\section{Acknowledgements}

The authors acknowledge National Academy of Agricultural Science for financial (RDA, PJ011853) and technical supports.

\section{Funding}

This work was supported by the Rural Development Administration Basic Research project, PJ011853.

\section{Availability of data and materials}

All data are available on Journal portals in submitted manuscript. No other supporting files/data are needed along with this submission.

\section{Competing interests}

The authors declare that they have no competing interests.

\section{Authors' contributions}

MY performed most of the experiments, prepared the manuscript: conceived of the study, participated in its design and coordination, collected and analyzed data, and prepared the manuscript. BJ carried out the animal studies, participated in oxidative relating enzyme assay. HJ carried out cytokine assays. JS participated in the genetic sequence alignment. KK participated in DNA microarray. YS carried out in vivo study of resistance artery responsiveness. All authors read and approved the final manuscript.

\section{Consent for publication}

This manuscript does not contain any individual person's data in any form.

\section{Ethics approval}

Studies involving animals were approved by the Laboratory Animals' Ethical Committee of the National Academy of Agricultural Science, RDA, South Korea (NAAS1503).

Manuscripts reporting studies did not contain human participants, human data or human tissues.

\section{Publisher's Note}

Springer Nature remains neutral with regard to jurisdictional claims in published maps and institutional affiliations.

\section{Author details}

'Department of Agricultural Biology, National Academy of Agricultural Science, Rural Development Administration (RDA), Wanju-Gun 55365, South Korea. ${ }^{2}$ College of Pharmacy, Ajou University, Suwon 442-749, South Korea. ${ }^{3}$ Pharmacogenechips Inc., Chuncheon 200-160, South Korea.

Received: 19 January 2017 Accepted: 30 March 2017

Published online: 21 April 2017

\section{References}

1. Eisenberg T, Abdellatif M, Schroeder S, Primessnig U, Stekovic S, Pendl T, Harger A, Schipke J, Zimmermann A, Schmidt A, Tong M, Ruckenstuhl C, Dammbrueck C, Gross AS, Herbst V, Magnes C, Trausinger G, Narath S, Meinitzer A, Hu Z, Kirsch A, Eller K, Carmona-Gutierrez D, Buttner S, Pietrocola F, Knittelfelder O, Schrepfer E, Rockenfeller P, Simonini C, Rahn A, Horsch M, Moreth K, Beckers J, Fuchs H, Gailus-Durner V, Neff F, Janik D, Rathkolb B, Rozman J, de Angelis MH, Moustafa T, Haemmerle G, Mayr M, Willeit $\mathrm{P}$, von Frieling-Salewsky M, Pieske B, Scorrano L, Pieber T, Pechlaner R, Willeit J, Sigrist SJ, Linke WA, Muhlfeld C, Sadoshima J, Dengjel J, Kiechl S, Kroemer G, Sedej S, Madeo F. Cardioprotection and lifespan extension by the natural polyamine spermidine. Nat Med. 2016. doi: 10.1038/nm.4222.

2. Ryan CN, Sorushanova A, Lomas AJ, Mullen AM, Pandit A, Zeugolis DI. Glycosaminoglycans in tendon physiology, pathophysiology, and therapy. Bioconjug Chem. 2015;26:1237-51.

3. Scott JE, Bosworth TR, Cribb AM, Taylor JR. The chemical morphology of age-related changes in human intervertebral disc glycosaminoglycans from cervical, thoracic and lumbar nucleus pulposus and annulus fibrosus. J Anat. 1994;184:73-82.

4. Schmidit JR, Lkiemt S, Preissler C, Noeller S, von Bergen M, Hempel U, Kalkhof. Osteroblast-realsed matrix vesicles, regulation of activity and composition by sulfated and non-sulfated glycosaminoglycans. Mol Cel Proteomics. 2016;15:558-72. 
5. Tomaszewski KA, Walocha JA, Mizia E, Gładysz T, Głowacki R, Tomaszewska R. Age- and degeneration-related variations in cell density and glycosaminoglycan content in the human cervical intervertebral disc and its endplates. Pol J Pathol. 2015;66:296-309.

6. Basappa, Rangappa KS, Sugahara K. Roles of glycosaminoglycans and glycanmimetics in tumor progression and metastasis. Glycoconj. 2014;31:461-7.

7. Labat-Robert J, Robert L. Aging of connective tissues: experimental facts and theorectial considerations. Interdiscip Top Gerontol. 2014;39:108-41.

8. Williamson KA, Hamilton A, Reynold JA, Sipos P, Crocker I, Stringer SE, Alexander YM. Age-related impairment of endothelial progenitor cell migration correlates with structural alterations of heparin proteoglycans. Aging Cell. 2013;12:139-47.

9. Ahn MY, Hahn BS, Ryu KS, Kim JW, Kim YS. Purification and characterization of a serine protease with fibrinolytic activity from dung beetles, Catharsius molossus. Thromb Res. 2003;112:339-47.

10. Kim HJ, Kim BJ, Ahn MY. Anti-oxidative and anti-hyperglycemia effects of dung beetle extracts on the high fat diet SD rats. J Life Sci. 2016;26:772-81.

11. Choi H, Hwang JS, Lee DG. Coprisin exerts antibacterial effects by inducing apoptosis-like death in Escherichia coli. IUBMB Life. 2016;68:72-8.

12. Ahn MY, Han JW, Yoon HJ, Hwang JS, Yun EY. Anti-inflammatory effect of bumblebee alcohol extracts in CFA-induced rat edema. Toxicol Res. 2012;28:249-53.

13. Hou L, Huang J, Green CD, Boyd-Kirkup J, Zhang W, Yu X, Gong W, Zhou B, Han JD. Systems biology in aging, linking in old and the young. Curr Genomics. 2012;13:558-65.

14. Weindruch R, Kayo T, Lee CK, Prolla TA. Microarray profiling of gene expression in aging and its alteration by caloric restriction in mice. J Nutr. 2001;131:918S-23S.

15. Martyniak K, Masternak MM, Changes in adipose tissue cellular composition during obesity and aging as a cause of metabolic dysregulation. Exp Gerontol. 2016. doi: 10.1016/j.exger.2016.12.007.

16. Cheung H, Multhaupt HAB, Oh ES, Couchman JR. Minireview: syndecans and their crucial roles during tissue regeneration. FEBS Letters. 2016;590: 2408-17.

17. Kim YS, Jo YY, Chang IM, Toida T, Park Y, Linhardt RJ. A new glycosaminoglycan from the giant african snail Achatina fulica. J Biol Chem. 1996;271:11750-5.

18. Kim ID, Ha BJ. The effects of paeoniflorin on LPS-induced liver inflammatory reactions. Arch Pharm Res. 2010;33:959-66.

19. Kang KS, Kim ID, Kwon RH, Lee JY, Kang JS, Ha BJ. The effects of fucoidan extracts on $\mathrm{CCl}_{4}$-induced liver injury. Arch Pharm Res. 2008;31:622-7.

20. Ueno T, Fukuda N, Nagase H, Tsunemi A, Tahira K, Matsumoto T, HiraokaYamamoto J, Ikeda K, Mitsumata M, Sato Y, Soma M, Matsumoto K, Yamori $Y$. Atherogenic dyslipidemia and altered hepatic gene expression in SHRSP.

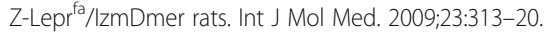

21. Song J, Liu H, Ressom HW, Tiwari S, Ecelbarger CM. Chronic rosigiltazone therapy normalizes expression of ACE1, SCD1 and other genes in the kidney of obese Zucker rats as determined by microarray by microarray analysis. Exp Clin Endocrinol Diabetes. 2008;116:315-25.

22. Jung YS, Moon CH, Cho TS, Yoo SE, Shin HS. Cardioprotective effects of KR30450, a novel K+(ATP) opener, and its major metabolite KR-30818 on isolated rat hearts. Jpn J Pharmacol. 1998;76:65-73.

23. Nomura Y. Structural change in decorin with skin aging. Connect Tissue Res. 2006:47:249-55.

24. Zia F, Zia KM, Zuber M, Tabasum S, Rehman S. Heparin based polyurethanes: a state-of-the-art review. Int J Biol Macromol. 2016;84:101-11.

25. Lu J, Sun Q, Tu ZC, Ly Q, Shui PX, Cheng YX. Identification of Nacetyldopamine dimmers from the dung beetle Catharsius molossus and their COX-1 and COX-2 inhibitory activities. Molecules. 2015;20:15589-96.

26. Ma J, Xin C, Tan C. Preparation, Physiochemical and pharmacoceutical characterization of chitosan from Catharsius molossus residue. Int J Biol Macromol. 2015;80:547-56.

27. Xin C, Ma JH, Tan CJ, Yang Z, Ye F, Long C, Ye S, Hou DB. Preparation of melanin from Catharsius molossus L. and preliminary study on its chemical structure. J Biosci Bioeng. 2015;119:446-54.

28. Ahn MY, Hahn BS, Ryu KS, Kim YS. Purification and characterization of a serine protease (CPM-2) with fibrinolytic activity from dung beetle. Arch Pharm Res. 2005;28:816-22.

29. Wan H, Kim BY, Lee KS, Yoon HJ, Lee KY, Jin BR. A bumblebee (Bombus ignitus) venom serine protease inhibitor that acts as a microbial serine protease inhibitor. Comp Biochem Physiol B Biochem Mol Biol. 2014;167:59-64.
30. Hu Z, Lee KS, Choo YM, Yoon HJ, Lee SM, Lee JH, Kim DH, Sohn HD, Jin BR. Molecular cloning and characterization of 1-Cys and 2-Cys peroxiredoxins from the bumblebee Bombus ignitus. Comp Biochem Physiol B Biochem Mol Biol. 2010;155:272-80.

31. You H, Wan H, Li J, Jin BR. Molecular cloning and characterization of a short peptidoglycan recognition protein (PGRP-S) with antibacterial activity from the bumblebee Bombus ignites. Dev Comp Immunol. 2010;34:977-85.

32. Yan $\sqcup$. Positive oxidative stress in aging and aging related disease tolerance. Redox Biol. 2014;2:165-9.

33. Valapala M, Edwards M, Hose S, Grebe R, Bhutto IA, Cano M, Berger T, Mak TW Wawrousek E, Handa JT, Lutty GA, Samuel Zigler Jr J, Sinha D. Increased Lipocalin-2 in the retinal pigment epithelium of cryba1 cKO mice is associated with a chronic inflammatory response. Aging Cell. 2014;13:1091-4.

34. Mussap M, Noto A, Cibecchini F, Fanos V. The importance of biomarkers in neonatology. Semin Fetal Neonatal Med. 2013;18:56-64.

35. Assis DM, Zalazar L, Juliano MA, De Castro R, Cesari A. Novel inhibitory activity for serine protease inhibitor Kazal type-3 (Spink3) on human recombinant kallikreins. Protein Pept Lett. 2013;20:1098-107.

36. Lynch K, Pei M. Age associated communication between cells and matrix: a potential impact on stem cell-based tissue regeneration strategies. Organogenesis. 2014;10:289-98.

37. Yoshimura R, Takai M, Namaki H, Minami K, Imamura W, Kato H, Kamel Y, Kanamoto R. Down regulation of asparagines synthetase and 3phosphlycerate dehydrogenase, and the up-regulation of serine dehydrates in rat liver from intake of excess amount of leucine are related to leucinecaused amino acid imbalance. J Nutr Sci Vitaminol (Tokyo). 2015;61:441-8.

38. Jeyakumar SM, Sheril A, Vajreswari A. Chronic vitamin A-enriched diet feeding induces body weight gain and adiposity in learn and glucoseintolerant obese rats of WNINN/GR-Ob strain. Exp Physiol. 2015;100:1352-61.

39. Law IKM, Xu A, Lam KSL, Berger T, Mak TW, Vanhoutte PM, Liu JTC, Sweeney G, Zhou M, Yang B, Wang Y. Lipocalin-2 deficiency attenuates insulin resistance associates with aging and obesity. Diabetes. 2010;59:872-82.

40. Unno K, Konishi T. Prevention effect of soybean on brain aging and amyloid- $\beta$ accumulation comprehensive analysis of brain gene expression. Recent Pat Food Agric. 2015;7:83-91.

41. Stehle Jr JR, Leng X, Kitzman DW, Nicklas BJ, Kritchevsky SB, High KP. Lipopolysaccharide-binding protein, a surrogate marker of microbial translocation, is associated with physical function in healthy older adults. J Gerontol A Biol Sci Med Sci. 2012;67:1212-8.

42. Sagripanti A, Carpi A. Natural anticoagulants, aging, and thromboembolism. Exp Gerontol. 1998;33:891-6.

43. Heinzelmann M, Bosshart H. Heparin binds to lipopolysaccahride (LPS)-binding protein, facilitates the transfer of LPS to CD14, and enhances LPS-induced activation of peripheral blood monocytes. J Immunol. 2005;174:2280-7.

44. Chen W, Han BC, Wang RC, Xiong GF, Peng JP. Role of secretory protease inhibitor SPINK3 in mouse uterus during early pregnancy. Cell Tissue Res. 2010;34:441-51.

45. Neuschwander-Tetri BA, Fimmel CJ, Kladney RD, Wells LD, Talkad V. Differential expression of the trypsin inhibitor SPINK3 mRNA and the mouse ortholog of secretory granule protein ZG-16p mRNA in the mouse pancreas after repetitive injury. Pancreas. 2004;28:e104-111.

46. Gaviriel P, Kagan H. Inhibition by heparin of the oxidation of lysine in collagen by lysyl oxidase. Biochemistry. 1988;27:2811-5.

47. Schupp M, Leferva MI, Janke J, Leitner K, Cristancho AG, Mullican SE, Qatanani M, Szwergold N, Steger DJ, Curtin JC, Kim RJ, Suh MJ, Albert MR, Engeli S, Gudas LJ, Lazar MA. Retinol saturase promotes adipogenesis and its downregulated in obesity. Proc Natl Acad Sci U S A. 2009;106:1105-10.

48. Murphy RA, Register TC, Shively CA, Carr JJ, Ge Y, Heilbrun ME, Steven R, Cummings SR, Koster A, Nevitt MC, Satterfield S, Tylvasky FA, Strotmeyer ES, Newman AB, Simonsick EM, Scherzinger A, Goodpaster BH, Launer LJ, Eiriksdottir G, Sigurdsson S, Sigurdsson G, Gudnason V, Lang TF, Kritchevsky SB, Harris TB. Adipose tissue density, a novel biomarker predicting mortality risk in older adults. J Gerontol A Biol Sci Med Sci. 2014;69:109-17. 